\title{
Article \\ Community Knowledge of and Attitudes towards COVID-19 Prevention Techniques in Saudi Arabia: A Cross-Sectional Study
}

\author{
Amal Khalil AbuAlhommos *D, Fatimah Essa Alhadab, May Mohammed Almajhad, Rahmah Almutawaa \\ and Sara Taleb Alabdulkareem
}

check for updates

Citation: AbuAlhommos, A.K.; Alhadab, F.E.; Almajhad, M.M.; Almutawaa, R.; Alabdulkareem, S.T. Community Knowledge of and Attitudes towards COVID-19 Prevention Techniques in Saudi Arabia: A Cross-Sectional Study. Int. J. Environ. Res. Public Health 2021, 18, 12783. https://doi.org/10.3390/ ijerph182312783

Academic Editor: Paul B. Tchounwou

Received: 1 November 2021

Accepted: 28 November 2021

Published: 3 December 2021

Publisher's Note: MDPI stays neutral with regard to jurisdictional claims in published maps and institutional affiliations.

Copyright: (c) 2021 by the authors. Licensee MDPI, Basel, Switzerland. This article is an open access article distributed under the terms and conditions of the Creative Commons Attribution (CC BY) license (https:/ / creativecommons.org/licenses/by/ $4.0 /)$.
Pharmacy Practice Department, Clinical Pharmacy College, King Faisal University, Hofuf 31982, Saudi Arabia; fatimessa08@gmail.com (F.E.A.); may24426@gmail.com (M.M.A.); r1_r2_@hotmail.com (R.A.); talebsara4@gmail.com (S.T.A.)

* Correspondence: aabualhomos@kfu.edu.sa

\begin{abstract}
The purpose of the study was to assess the community knowledge of and to obtain a broad overview of attitudes towards appropriate prevention techniques that are recommended by the Ministry of Health to prevent COVID-19 transmission in Saudi Arabia. Methods: A cross-sectional study using an online survey was conducted in Saudi Arabia between 1 May and 30 November 2020 to assess the community knowledge of and attitudes towards appropriate COVID-19 prevention techniques in Saudi Arabia. The study tool was developed based on an extensive literature review. Results: A total of 577 individuals were involved in this study. The majority of the participants knew that COVID-19 is classified as a severe acute respiratory syndrome, is caused by viral infection, and that it is more common among the elderly and those who have a chronic illness. More than half of the participants were able to identify the symptoms of COVID-19 correctly, which are fever, dry cough, and loss of taste. Approximately half the study participants were knowledgeable about appropriate distancing, handwashing, and preventive measures (e.g., wearing a cloth mask, smoking cessation, avoiding dangerous cultural behaviors that increase the probability of disease transmission). More than half of the study participants were able to identify the appropriate actions that should be taken if common COVID-19 symptoms appear. Conclusion: A promising level of knowledge and positive attitudes towards COVID-19 was observed in Saudi Arabia. Continuous efforts should be maintained to sustain the level of awareness among the public. Further studies are warranted to explore the level of knowledge and attitudes after the introduction of COVID-19 vaccines.
\end{abstract}

Keywords: attitudes; community; COVID-19; knowledge; prevention

\section{Introduction}

Coronavirus disease 2019 (COVID-19), an infectious disease that emerged in China, is caused by a virus from the family Coronaviridae, which comprises positive-stranded RNA viruses. The family can be divided into four genera: Alphacoronavirus, Betacoronavirus, Deltacoronavirus, and Gammacoronavirus. In December 2019, in Wuhan City, China, scientists discovered a betacoronavirus that causes severe acute respiratory syndrome, coronavirus 2 (SARS-CoV-2), which is similar to a virus found in bats. It can be transmitted by close contact between people through the respiratory droplets of an infected person [1-6]. Additionally, literature findings show that SARS-CoV-2 aerosol transmission is possible [7].

The life cycle of the virus within the host consists of five steps: The first step is attachment, when the virus binds to the receptors of the host. The second step, penetration, is when the virus enters cells by endocytosis. The third step is biosynthesis, whereby the RNA of the virus enters the nucleus of cells and starts replicating. The fourth step is maturation, in which the viral content is made. Finally, in the fifth step, the viral content is released. Coronaviruses contain different proteins, such as envelope, nucleocapsid, spike, 
and membrane. The spike protein in SARS-CoV-2 binds to ACE2 receptors in the host, which are highly expressed in the lung, kidneys, and heart. It enters lung epithelial cells and destroys them, causing lung injury. In response to this injury, macrophages start fighting this virus and T cells also act in response to this virus [8]. Mutation is defined as a change in the genetic sequence [9]. Genomes that differ from each other in genetic sequence are called variants. Variants can differ from each other by one or more mutations. When a phenotypic difference is demonstrated among the variants, they are called strains [10]. The SARS-CoV-2 genome is subject to multiple mutations that lead to antigenic drift which can lead to escape from immune recognition. Different variants have been identified during the pandemic in different countries. The most important three, which have rapidly become dominant, are the UK variant (Alpha variant), the South African variant (Beta variant), and the Brazilian variant (Gamma variant) [11].

The most important factors that can exacerbate the spread of COVID-19 include travelling to an area that has a high risk of transmission, older age (patients older than 50 years), having comorbidities such as cardiovascular disease, hypertension, diabetes, respiratory disease, smoking, liver disease, cancer, organ transplant, and immunosuppression, and pregnancy [4]. The clinical presentations of patients who are suspected of having COVID-19 are fever, cough, dyspnoea, loss of the sense of smell and taste, fatigue, sputum production, sore throat, neurological symptoms, nasal congestion, chest pain, tachypnea, tachycardia, and cyanosis. Certain diagnostic tests should be conducted in patients suspected of having COVID-19. These tests include reverse transcription-polymerase chain reaction (RT-PCR) tests, arterial blood gas (ABG) tests, full blood count (FBC), serum interleukin-6 level test, chest $\mathrm{x}$-rays, computed tomography (CT) test, lung ultrasound, and SARS-CoV-2 nucleic acid testing [8].

We can prevent the transmission and the spread of COVID-19 in different ways. Firstly, we can practice hand hygiene by washing our hands with soap and water or using an alcohol-based hand rub. Social distancing is also encouraged, whereby individuals should maintain a distance from each other of at least one meter, which is equal to three feet, to prevent the transmission of infected droplets through sneezing and coughing. People should stay away from crowded areas to prevent contact with an infected person. When people leave the house, they should practice respiratory hygiene by using a tissue while sneezing or coughing, or by covering their mouth and nose with a bent elbow. Following this, people should wash their hands and throw the tissue away. If a person has any symptoms, he/she should isolate themselves at home until these symptoms disappear, and if they must leave the house, they should wear a mask to prevent spreading the virus to other people. If they have a fever, difficulty breathing, and cough, they should contact a doctor and seek medical attention. Covering the mouth and nose with a mask is mandatory. Surgical masks and N95 respirators are recommended for healthcare workers [12]. While previous studies in Saudi Arabia have focused on the clinical and mental consequences of COVID-19 [13-17], very few studies have explored community knowledge and attitudes towards the disease, and most of them are restricted to a specific governorate or area. Therefore, this study aimed to assess the community knowledge of and to obtain a broad overview of attitudes towards the appropriate prevention techniques that are recommended by the Ministry of Health (MOH) to prevent COVID-19 transmission in Saudi Arabia before the emergence of COVID-19 drift variants.

\section{Methods}

\subsection{Study Design}

A cross-sectional study using an online survey was conducted in Saudi Arabia between 1 May and 30 November 2020 to assess the community knowledge of and attitudes towards appropriate COVID-19 prevention techniques in Saudi Arabia. 


\subsection{Sampling Strategy}

Eligible participants were invited to participate in the study using a convenience sampling technique. The general population was invited to participate in the study through social media platforms (Facebook and WhatsApp). General Facebook and WhatsApp groups were utilized to distribute the study invitation letter, together with the survey participation link. These included groups that discuss customer services, healthy food, and restaurants and cafes, which include a large number of members with different sociodemographic characteristics.

All participants voluntarily participated in the study and were thus considered exempt from written informed consent. The survey was distributed through dedicated pages/groups in the social media platforms (Facebook and WhatsApp). The survey distribution post requested the participants to participate in the study and share the post with their friends and network. The study aims and objectives were clearly explained at the beginning of the survey. The inclusion criteria were participants aged 18 years and above, currently living in Saudi Arabia. Participants were excluded if they were below 18 years of age.

\subsection{Study Tool}

The study tool was developed based on an extensive literature review. It comprised three sections. The first section, which addressed the participants' demographics, comprised five questions about age, gender, nationality, education level, and employment status. The second section of the questionnaire addressed participants' knowledge about COVID-19 (16 questions), including its symptoms, methods of transmission, and prevention techniques. The third section of the questionnaire was composed of 11 questions and addressed participants' attitudes towards the appropriate prevention techniques that are recommended by $\mathrm{MOH}$, Appendix A.

\subsection{Sample Size}

Using a confidence interval of $95 \%$, a standard deviation of 0.5 , and a margin of error of $5 \%$, the required sample size was 385 participants.

\subsection{Statistical Analysis}

Descriptive statistics were used to describe participants' demographic characteristics. Continuous data were reported as a mean \pm SD for normally distributed variables. Categorical data were reported as percentages (frequencies). A two-tailed $p<0.05$ was considered statistically significant. The statistical analyses were carried out using SPSS (version 25).

\section{Results}

A total of 577 individuals were involved in this study. The majority $(77.1 \%, n=445)$ were females. Approximately $46.0 \%$ were aged $18-29$ years. Approximately half $(56.8 \%$, $n=328)$ had a bachelor's degree. Approximately $35.7 \%(n=206)$ were without a job. For further details on the characteristics of the study participants, refer to Table 1. 
Table 1. Participants' demographic characteristics.

\begin{tabular}{|c|c|}
\hline Demographic Variable & Frequency $(\%)$ \\
\hline \multicolumn{2}{|c|}{ Age category } \\
\hline $18-29$ years & $265(45.9)$ \\
\hline 30-39 years & $160(27.7)$ \\
\hline 40-49 years & $116(20.1)$ \\
\hline 50-59 years & $30(5.2)$ \\
\hline 60 years and above & $6(1.0)$ \\
\hline \multicolumn{2}{|c|}{ Gender } \\
\hline Female & $445(77.1)$ \\
\hline \multicolumn{2}{|c|}{ Nationality } \\
\hline Saudi & $570(98.8)$ \\
\hline \multicolumn{2}{|c|}{ Education level } \\
\hline Primary education & $5(0.9)$ \\
\hline High school level & $222(38.5)$ \\
\hline Bachelor degree & $328(56.8)$ \\
\hline Post graduate degree & $22(3.8)$ \\
\hline \multicolumn{2}{|c|}{ Employment status } \\
\hline Without job & $206(35.7)$ \\
\hline Student & $160(27.7)$ \\
\hline Retired & $21(3.6)$ \\
\hline Has a job outside the medical field & $145(25.1)$ \\
\hline Has a job in the medical field & $45(7.8)$ \\
\hline
\end{tabular}

\subsection{Knowledge about COVID-19}

Table 2 below highlights participants' knowledge about COVID-19. The Ministry of Health was the main source of information for approximately two-thirds $(68.3 \%)$ of the study participants. Approximately, $84.7 \%(n=489)$ of the participants were aware that COVID-19 is classified as a severe acute respiratory syndrome. A majority of $97.4 \%(n=562)$ of the participants knew that it was discovered initially in Wuhan, China. The same percentage of the participants knew that it causes viral infection. The majority of the participants identified that direct contact with an infected person, respiratory droplets, and touching contaminated surfaces are common causes of COVID-19 transmission. Approximately $62.0 \%$ of the participants were able to identify the symptoms of COVID-19 correctly, which are fever, dry cough, and loss of taste. The vast majority $(96.2 \%, n=555)$ of the participants knew that severe illness with COVID-19 is more common among the elderly and those who have a chronic illness. Approximately half of the participants (49.0\%) knew that a distance between individuals of two to three meters is the method for the prevention of COVID-19 recommended by the $\mathrm{MOH}$. Approximately half of the participants (48.0\%) acknowledged that there is treatment for the disease. Approximately $40.0 \%$ of the participants were able to identify the appropriate duration for handwashing ( $40 \mathrm{~s}$ ) and when using alcohol for hand hygiene (20 s). The majority $(85.1 \%, n=491)$ were able to identify that wearing a cloth mask is an appropriate procedure to decrease the risk of infection; however, only $4.5 \%$ of the participants were able to identify that smoking cessation decreases the risk of getting infected with the disease. Only one-third of the study participants were able to identify the proper steps for handwashing. Approximately $75 \%$ were able to identify the best method after sneezing and coughing to reduce transmission of COVID-19, which is covering the mouth and nose with a tissue and then washing one's hands. Additionally, the vast majority $(84.6 \%)$ were able to identify conditions that require patients to isolate at home. 
Table 2. Participants' knowledge about COVID-19.

\begin{tabular}{|c|c|}
\hline Variable & Frequency $(\%)$ \\
\hline \multicolumn{2}{|c|}{ What is Coronavirus disease (COVID-19)? } \\
\hline Severe Acute Respiratory Syndrome & $489(84.7)$ \\
\hline Seasonal Influenza & $51(8.8)$ \\
\hline Common Cold disease & $7(1.2)$ \\
\hline I don't know & $30(5.2)$ \\
\hline \multicolumn{2}{|c|}{ Where COVID-19 was discovered initially? } \\
\hline In Wuhan, China & $562(97.4)$ \\
\hline In the United States & $4(0.7)$ \\
\hline In Saudi Arabia & $2(0.3)$ \\
\hline I don't know & $9(1.6)$ \\
\hline \multicolumn{2}{|l|}{ COVID-19 is considered as? } \\
\hline Viral infection & $562(97.4)$ \\
\hline Bacterial infection & $10(1.7)$ \\
\hline I don't know & $5(0.9)$ \\
\hline \multicolumn{2}{|c|}{ COVID-19 can be transmitted by (you can choose more than one option)? } \\
\hline Direct contact with infected person & $491(85.1)$ \\
\hline Direct person droplet & $475(82.3)$ \\
\hline Touching contaminated surfaces & $458(79.4)$ \\
\hline Blood transfusion & $100(17.3)$ \\
\hline Stools & $25(4.3)$ \\
\hline I don't know & $1(0.1)$ \\
\hline \multicolumn{2}{|c|}{ COVID-19 symptoms are (you can choose more than one option)? } \\
\hline Fever, dry cough, and loss of taste & 357 (61.9) \\
\hline Fever, dry cough, and shortness of breath & $217(37.6)$ \\
\hline Fever, vomiting, and skin rash & $1(0.2)$ \\
\hline I don't know & $2(0.3)$ \\
\hline \multicolumn{2}{|c|}{ Covid-19 more likely to be severe in? } \\
\hline Elderly and have chronic illnesses & $555(96.2)$ \\
\hline Children & $9(1.6)$ \\
\hline Elderly and have no chronic illnesses & $5(0.9)$ \\
\hline Pregnant women & $1(0.2)$ \\
\hline \multicolumn{2}{|c|}{ What are the prevention methods that were recommended by MOH? } \\
\hline Distance between you and your partner 2 to $3 \mathrm{~m}$ & $283(49.0)$ \\
\hline Stay at home to help reduce spread of virus & $174(30.2)$ \\
\hline Avoid crowded area more than 25 person & $83(14.4)$ \\
\hline Clean hand for $2 \mathrm{~min}$ & $35(6.1)$ \\
\hline I don't know & $2(0.3)$ \\
\hline \multicolumn{2}{|c|}{ Did you know if we have any curable therapy } \\
\hline Yes & $279(48.4)$ \\
\hline
\end{tabular}


Table 2. Cont.

\begin{tabular}{cc}
\hline Variable & Frequency (\%) \\
\hline How many seconds should we take in washing our hand? & \\
\hline $20 \mathrm{~s}$ & $214(37.1)$ \\
\hline $25 \mathrm{~s}$ & $20(3.5)$ \\
\hline $30 \mathrm{~s}$ & $115(19.9)$ \\
\hline $40 \mathrm{~s}$ & $228(39.5)$ \\
\hline Did you use alcohol hygiene, if yes how long? \\
\hline $10 \mathrm{~s}$ & $223(38.6)$ \\
\hline $20 \mathrm{~s}$ & $221(38.3)$ \\
\hline $30 \mathrm{~s}$ & $64(11.1)$ \\
\hline $40 \mathrm{~s}$ & $69(12.0)$
\end{tabular}

Do you think any one of the following procedures may reduce the risk of infection by COVID-19?

\begin{tabular}{cc}
\hline Wearing cloth masks & $491(85.1)$ \\
\hline Taking herbal remedies & $36(6.2)$ \\
\hline Smoking cessation & $26(4.5)$ \\
\hline Taking of antibiotics & $24(4.2)$ \\
\hline In the steps of washing hands we should consider: \\
\hline
\end{tabular}

Wet hands, rub palms together, interlink your fingers, rub palms with your fingers, rub the back of hands, then thoroughly rinse with water.

Wet hands, rub palms together, interlink your fingers, rub the back of hands, rub palms with your fingers, then thoroughly rinse with water.

Wet hands, rub palms together, rub the back of hands, interlink your

fingers, rub palms with your fingers, then thoroughly rinse with water.

$$
\text { I don't know } 23(4.0)
$$

Best method after sneezing and coughing to reduce transmission of COVID-19:

Cover mouth and nose with tissue and then washing hands $430(74.5)$

Cover mouth and nose with arm $107(18.5)$

Cover mouth and nose with tissue $38(6.6)$

I don't know

The condition that is required for patients who need home isolation:

Separate bathroom, staying in private room, Surface disinfection,

especially door handles, open window frequently, use disposable materials that is for one use only.

Shared bathroom with the family, staying in a private room, disinfecting surfaces, especially door handles, opening the window frequently,

$$
\text { I don't know }
$$

Do you think if there was vaccination to COVID-19:

$$
\text { Yes }
$$

From where you got your information about COVID-19 prevention method:

\begin{tabular}{cc}
\hline Ministry of Health & $394(68.3)$ \\
\hline Social media & $127(22.0)$ \\
\hline Internet website & $43(7.5)$ \\
\hline From family and friends & $13(2.3)$ \\
\hline
\end{tabular}




\subsection{Attitudes towards COVID-19}

Table 3 below highlights participants' attitudes towards COVID-19. Approximately $60.0 \%$ of the study participants reported that they stay at home to reduce the spread of the virus most days during the week. Additionally, $36.0 \%$ reported that they go out only in case of emergency. Only $11.4 \%$ of the participants reported that they have attended gatherings that include more than 50 persons. The vast majority $(86.8 \%)$ reported that they avoid cultural behaviors such as shaking hands.

Table 3. Participants' attitudes towards COVID-19.

\begin{tabular}{|c|c|}
\hline Variable & Frequency $(\%)$ \\
\hline \multicolumn{2}{|c|}{$\begin{array}{l}\text { Did you stay at home to reduce the spread of virus most of the days during the week } \\
\text { (5 days or more)? }\end{array}$} \\
\hline Yes & $347(60.1)$ \\
\hline I go out in emergency case & $207(35.9)$ \\
\hline No & $23(4.0)$ \\
\hline \multicolumn{2}{|c|}{ Did you attend any celebration site that include more than 50 persons? } \\
\hline Yes & $66(11.4)$ \\
\hline \multicolumn{2}{|c|}{ Did you keep the distance ( 1 to $2 \mathrm{~m}$ ) between you and others to avoid spread of COVID-19? } \\
\hline Yes & $501(86.8)$ \\
\hline \multicolumn{2}{|c|}{ Have you recently avoided cultural behaviors, such as shaking hands? } \\
\hline Yes & $496(86.0)$ \\
\hline \multicolumn{2}{|c|}{ Did you wash your hand by water and soap after following situation? } \\
\hline After sneezing and coughing & $435(75.4)$ \\
\hline Before and after take care of infected person in home & $424(73.5)$ \\
\hline After leaving the toilet & $389(67.4)$ \\
\hline Before meal & $94(16.3)$ \\
\hline After touching the garbage & $42(7.3)$ \\
\hline After touching animals (pets) & $36(6.2)$ \\
\hline After leaving home & $13(2.3)$ \\
\hline I don't do & $2(0.3)$ \\
\hline \multicolumn{2}{|c|}{ If COVID-19 common symptoms appear, patient must do the following: } \\
\hline Wear face mask, wear gloves and contact the emergency & $416(72.1)$ \\
\hline Wear face shield, Wear face mask and stay at home & 109 (18.9) \\
\hline Wear face mask and stay at home & $41(7.1)$ \\
\hline Wear face mask and wear gloves & $11(1.9)$ \\
\hline \multicolumn{2}{|c|}{ In case of you visit clinic and your result was negative, what you will do? } \\
\hline Commitment to preventive precautions that applied by $\mathrm{MOH}$ & $438(75.9)$ \\
\hline Home quarantine for 14 days & $89(15.4)$ \\
\hline Home isolation for 10 days & $45(7.8)$ \\
\hline Contact the emergency & $5(0.9)$ \\
\hline \multicolumn{2}{|c|}{$\begin{array}{l}\text { In case of you visit clinic and your result was negative, and you are in previous contact with } \\
\text { COVID-19 confirmed case. What you will do? }\end{array}$} \\
\hline Home quarantine for 14 days & $347(60.1)$ \\
\hline Home isolation for 10 days & $116(20.1)$ \\
\hline Commitment to preventive precautions that applied by $\mathrm{MOH}$ & $64(11.1)$ \\
\hline Contact the emergency & $50(8.7)$ \\
\hline
\end{tabular}


Table 3. Cont.

\begin{tabular}{cc}
\hline Variable & \multicolumn{1}{c}{ Frequency (\%) } \\
\hline $\begin{array}{c}\text { In case of you visit clinic and your result was positive without symptoms, and you aren't in } \\
\text { previous contact with COVID-19 confirmed case. What you will do? }\end{array}$ & $223(38.6)$ \\
\hline Home isolation for 10 days & $206(35.7)$ \\
\hline Home quarantine for 14 days & $120(20.8)$ \\
\hline Commitment to preventive precautions that applied by MOH & $28(4.9)$ \\
\hline Contact the emergency & 347 (69.1) \\
\hline Contact the emergency & $136(23.6)$ \\
\hline Home quarantine for 14 days & $61(10.6)$ \\
\hline Commitment to preventive precautions that applied by MOH & $33(5.7)$ \\
\hline Home isolation for 10 days & 189 (32.8) \\
\hline In the case of positive COVID-19 Patient and there is no place for isolation in his house, what he \\
\hline most does: \\
\hline Contact the emergency & $139(24.1)$ \\
\hline Take precautions at home & $18(3.1)$ \\
\hline I don't know
\end{tabular}

The most common situations in which the study participants reported washing their hands with water and soap were after sneezing and coughing, before and after taking care of an infected person at home, and after using the toilet. Approximately $72.0 \%$ of the participants were able to identify the proper procedure if common COVID-19 symptoms appear, which is wearing a face mask, gloves, and seeking prompt medical care. In the case of visiting a clinic and receiving a negative result, the majority (75.9\%) reported that they would adhere to the preventive measures that were advised by the $\mathrm{MOH}$. If the result was negative and there had been previous contact with a confirmed COVID-19 case, approximately $60.0 \%$ reported that they would quarantine at home for 14 days.

In the case of visiting a clinic and receiving a positive result without symptoms, with no previous contact with a confirmed COVID-19 case, approximately one-third (35.7\%) reported that they would adhere to home quarantine for 14 days. If the result was positive and they had severe symptoms, approximately two-thirds (69.1\%) reported that they would seek emergency medical assistance. In the case of testing positive for COVID-19 without the option of isolating at home, approximately $40.0 \%$ reported that they would go to a hotel.

\section{Discussion}

This study aimed to assess the community knowledge of and attitude towards the appropriate prevention techniques that are recommended by MOH to prevent COVID-19 transmission in Saudi Arabia. The main findings of this study are: (1) the majority of the participants knew that COVID-19 is classified as a severe acute respiratory syndrome, causes viral infection, and that it is more common among the elderly and those who have a chronic illness; (2) more than half of the participants were able to identify the symptoms of COVID-19 correctly, which are fever, dry cough, and loss of taste; (3) approximately half the study participants were knowledgeable about the appropriate distancing, handwashing, and preventive measures (wearing a cloth mask, smoking cessation, avoiding dangerous cultural behaviors that increase the probability of disease transmission), and (4) more than half of the study participants were able to identify the appropriate actions that should be taken if common COVID-19 symptoms appear.

Overall, the participants in our study showed a very good level of knowledge regarding COVID-19 disease in terms of its symptoms, methods of transmission, and prevention 
techniques. This confirms the findings of previous studies on the level of knowledge among the general public in Saudi Arabia concerning previous epidemics, such as the Middle East respiratory syndrome (MERS) [18,19].

Proper knowledge about COVID-19 disease, its symptoms, methods of transmission, and prevention techniques are key factors that have contributed to the improvement in the epidemiological status of COVID-19 in Saudi Arabia. This is reflected positively in the number of daily new cases, active cases, and daily new deaths [20]. As of November 26, $2021,98 \%$ of COVID-19 cases were recovered/discharged, with only 2,049 active cases (with a prevalence rate of $0.006 \%$ ) in the whole country (the total population is 34.81 million) [20].

The majority of the participants in our study (84.7\%) were aware that COVID-19 is classified as a severe acute respiratory syndrome and causes viral infection (97.4\%). Most participants identified that direct contact with an infected person, respiratory droplets, and touching contaminated surfaces are common causes of COVID-19 transmission. Approximately $62.0 \%$ of the participants were able to identify the symptoms of COVID-19 correctly, which are fever, dry cough, and loss of taste. The vast majority $(96.2 \%)$ of the participants knew that severe illness with COVID-19 is more common among the elderly and those who have a chronic illness. Multiple factors might have contributed to the high level of knowledge about COVID-19 among our study participants. These include the high level of education and the young population [21-23]; in our study, more than half of our study population reported that they have a bachelor's degree or higher and more than one-third had a high-school education. A good level of knowledge has proven to be a predictor for adherence to precautionary measures during pandemics [24,25]. On the other hand, a lack of awareness and not having enough information about the disease leads to undesirable attitudes and practices, which ultimately leads to negative consequences for infection control [26].

Wearing a face mask and taking other precautionary measures are important actions that should be taken by the whole community and specifically by those who are sick or have a higher risk of getting infected $[27,28]$. Besides, there is a continuous need to follow social distancing to prevent the spread of the coronavirus.

In our study, more than half of the participants $(68.3 \%)$ reported that the $\mathrm{MOH}$ was the main source of information about COVID-19 followed by social media (22.0\%). Confirming the findings of a previous study that was conducted in Egypt, the $\mathrm{MOH}$ was one of the main sources of information to the general public about COVID-19 through its communication via different media platforms, including television, social media (Facebook), advertisements in the street, and mobile messages [21,29]. Communication should be clear and target the whole community taking into account individual differences [30,31]. A previous study highlighted that one of the main motivations of the general public to follow the guidance of the $\mathrm{MOH}$ regarding COVID-19 disease was to protect themselves and their family from getting infected with the disease [21]. The governmental authorities in Saudi Arabia have a great deal of experience in dealing with public health issues such as the COVID-19 pandemic. Two previous viral disease outbreaks that emerged in Saudi Arabia in the past decade, SARS and MERS [32-36], were managed with the highest possible healthcare standards that led to suppressing their spread and diminishing their clinical and economic impact on the general public.

In our study, the participants showed a positive attitude towards appropriate prevention techniques. Approximately $60.0 \%$ of the study participants reported that they stay at home to reduce the spread of the virus most days during the week, while $36.0 \%$ reported that they go out only in the event of emergency. Only $11.4 \%$ of the participants reported that they have attended celebrations that included more than 50 people. The vast majority $(86.8 \%)$ reported that they avoid certain cultural behaviors, such as shaking hands. A positive attitude could be justified due to the proactive protective measures taken by policymakers in Saudi Arabia, which has helped markedly in controlling the spread of the disease, despite the large population in Saudi Arabia and the heavy traffic of visitors who travel to Saudi Arabia for religious purposes. Preventive measures have 
included suspending religious visits to the country (Umrah), lockdown, and restrictions on international and domestic flights, public gatherings, and face-to-face education. This positive attitude of the general public reflects the trust in the government's actions in controlling the pandemic, which confirms the findings of previous studies [21,22,37].

In our study, most participants held positive attitudes towards controlling the spread of COVID-19, which was reflected in their practices. This was demonstrated by the precautionary measures that were reported, including practicing proper hygiene and avoiding crowded places. Approximately half of the participants (49.0\%) knew that maintaining a distance of two to three meters from other people is the recommended method for the prevention of COVID-19 by the MOH. Approximately $40.0 \%$ of the participants were able to identify the appropriate duration for handwashing (40 s) and when using alcohol for hygiene (20 s). The majority $(85.1 \%)$ were able to identify that wearing a cloth mask is an appropriate procedure to decrease the risk of infection; however, only $4.5 \%$ of the participants were able to identify that smoking cessation decreases the risk of becoming infected with the disease. Only one-third of the study participants were able to identify the proper steps for handwashing. Approximately $75 \%$ were able to identify the best method after sneezing and coughing to reduce transmission of COVID-19, which is covering the mouth and nose with a tissue and then washing one's hands.

Approximately $72.0 \%$ of the participants were able to identify the proper procedure if common COVID-19 symptoms appear, which is wearing a face mask, gloves, and seeking prompt medical assistance. More than half of the study participants were able to identify the appropriate actions that should be taken if common COVID-19 symptoms appear. These include adherence to the preventive measures as advised by the $\mathrm{MOH}$, quarantining at home for 14 days, and seeking emergency medical assistance in the case of severe symptoms. This confirmed the findings of previous studies that were conducted in Saudi Arabia and Egypt, highlighting the positive attitude of the general public $[21,29]$. This positive attitude has emerged from the general belief of the community in the effectiveness of the preventive measures that are recommended by the $\mathrm{MOH}$, the WHO, and other leading bodies in healthcare in the prevention of the spread of the disease, which was reflected clearly in the epidemiological curves of the country [38]. These positive attitudes and practices towards controlling the spread of COVID-19 and preventing its transmission are reflections of the preventive measures taken by the authorities in Saudi Arabia. Similar findings were found across different studies conducted in China and Malaysia [37,39].

Policymakers in governments are advised to continue their efforts in increasing the level of awareness regarding COVID-19 prevention and transmission in society. These efforts should be directed towards high-risk populations, including populations with lower socioeconomic status [40].

This study has limitations. The use of social media platforms to recruit participants could affect the socioeconomic and demographic characteristics (i.e., having a higher proportion of respondents from one gender over the other or including a younger population) of the study participants, which may result in bias and could affect the generalizability of the study findings. Our study excluded participants who were aged below 18 years, therefore, we might have omitted an important group of the community who might have a different level of knowledge and attitudes towards COVID-19. The use of an online survey for data collection could have missed some of the targeted population. However, this has been common research practice during the pandemic as a previous study has documented that the use of online evaluation platforms during the COVID-19 pandemic has increased significantly and specifically for education and research purposes [41]. However, due to the COVID-19 pandemic and in order to minimize the risk of disease transmission, we preferred not to undertake any direct (in person) recruitment and to use social media platforms instead. A further consideration is that the data collection extended over a period of six months, which could have led to changes in the level of knowledge over the time period. Finally, some questions that explored participants' attitudes towards COVID-19 used a yes/no format. This type of question might affect the participants' responses and 
lead to social desirability bias; the participants might provide a socially desired response regarding their own behavior and attitudes towards COVID-19.

\section{Conclusions}

Our study participants showed an encouraging level of knowledge and positive attitudes towards COVID-19. Continuous efforts should be maintained to sustain the level of awareness among the public. Further studies are warranted to explore the level of knowledge and attitudes after the introduction of COVID-19 vaccines. A study of the intermediate period (i.e., late 2021) would be useful to look at progression in awareness as vaccination programs develop. Additionally, future studies to show progressive changes in attitudes during the recovery period would be valuable.

Author Contributions: Conceptualization, A.K.A.; methodology, A.K.A.; software, A.K.A.; validation, A.K.A.; formal analysis, A.K.A.; investigation, A.K.A., F.E.A., M.M.A., R.A., and S.T.A.; resources, A.K.A., F.E.A., M.M.A., R.A., and S.T.A.; data curation, A.K.A., F.E.A., M.M.A., R.A., and S.T.A.; writing—original draft preparation, A.K.A., F.E.A., M.M.A., R.A., and S.T.A.; writing-review and editing, A.K.A., F.E.A., M.M.A., R.A., and S.T.A.; visualization, A.K.A., F.E.A., M.M.A., R.A., and S.T.A.; supervision, A.K.A.; project administration, A.K.A.; funding acquisition, A.K.A. All authors have read and agreed to the published version of the manuscript.

Funding: This study was supported by the Deanship of Scientific Research (DSR, Grant no. 216062), King Faisal University, AlAhsa, Saudi Arabia.

Institutional Review Board Statement: Ethical approval was obtained for this study from the Research Ethics Committee of Pharmacy Practice at the Clinical Pharmacy College at King Faisal University.

Informed Consent Statement: Informed consent was obtained from all subjects involved in the study.

Data Availability Statement: Not applicable.

Conflicts of Interest: The authors declare no conflict of interest.

\section{Appendix A}

Questionnaire tool

Assess Community knowledge of and attitudes towards COVID-19 prevention techniques in Saudi Arabia: a cross-sectional study.

Dear participant,

You are kindly requested to participate in our study which is aiming to assess the community knowledge of and get a broad overview of attitudes towards the appropriate prevention techniques that are recommended by the MOH to prevent COVID-19 transmission in Saudi Arabia.

Answer the following questions (choose one answer)

Demographic characteristics

\section{Gender}

$$
\text { Male }
$$

female

2. Age

$\begin{array}{ll}18-29 \\ 0 & 30-39 \\ & 40-49 \\ 50-59 \\ \text { Over } 60\end{array}$

3. Nationality

Saudi

Non-Saudi 
4. Education level

Uneducated

High school or less

Bachelor's degree

Post graduate degree

5. Employment status

Without job

Retired

Has a job in non-medical field

Has a job in medical field

Awareness about COVID-19 disease

6. what is Coronavirus disease (COVID-19)

Seasonal Influenza

Common Cold disease

Severe Acute Respiratory Syndrome

I don't know

7. where COVID-19 was discovered initially

in United State

in Saudi Arabia

in Egypt

in Wuhan city, China

I don't know

8. COVID-19 consider as

virus infection

bacterial infection

fungal infection

I don't know

9. COVID-19 can be transmitted by (you can choose more than one answer)

Touching contaminated surfaces

Direct contact with infected person

Direct person droplet

Blood transfusion

Stools

I don't know

10. COVID-19 symptoms are (you can choose more than one answer)

Fever, dry cough, shortness of breath

Fever, dry cough, loss of taste

Fever, vomiting, skin rash

I don't know

11. COVID-19 more likely to be severe in

children

elderly and have chronic illnesses

elderly and have no chronic illnesses

pregnant women

I don't know

Attitude towards COVID-19 disease

12. What are the prevention methods that were recommended by $\mathrm{MOH}$

Stay at home to help reduce spread of virus

Distance between you and your partner 2 to $3 \mathrm{~m}$

Avoid crowded area more than 25 person 
Clean hands for $2 \mathrm{~min}$

Answer the following question by yes or no

13. Did you stay at home to reduce the spread of virus most of the days during the week ( 5 days or more)

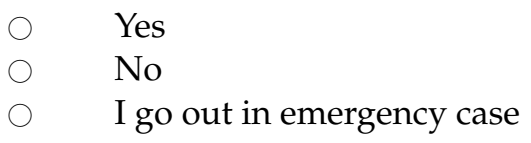

14. Did you attend any celebration site that include more than $\mathbf{5 0}$ persons?

Yes

No

15. Did you keep the distance ( 1 to $2 \mathrm{~m}$ ) between you and others to avoid spread of COVID-19
$\bigcirc \quad$ Yes
$\bigcirc \quad$ No

16. Have you recently avoided cultural behaviors, such as shaking hands?

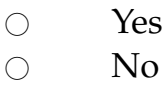

17. Did you know if we have any curable therapy

$$
\begin{aligned}
& \text { Yes } \\
& \text { No } \\
& \text { I don't know }
\end{aligned}
$$

18. Did you wash your hand by water and soap after following situation

After leaving the toilet

Before and after take care of infected person in home

After sneezing and coughing

After touching animals (pets)

After touching the garbage

Before meal

After leaving home

I don't do

19. How many seconds should we take in washing our hand?

$\begin{array}{cc}0 & 20 \mathrm{~s} \\ 0 & 30 \mathrm{~s} \\ 0 & 40 \mathrm{~s} \\ & 25 \mathrm{~s}\end{array}$

20. Did you use alcohol hygiene if yes how long
$20 \mathrm{~s}$
$40 \mathrm{~s}$
$30 \mathrm{~s}$
$10 \mathrm{~s}$

21. Do you think any one of the following procedures may reduce the risk of infection by COVID-19

Taking of antibiotics

Taking herbal remedies

Wearing cloth masks

smoking cessation

22. In the steps of washing hands we should consider.

Wet hands, rub palms together, rub the back of hands, interlink your fingers, rub palms with your fingers, then thoroughly rinse with water. 
Wet hands, rub palms together, interlink your fingers, rub the back of hands, rub palms with your fingers, then thoroughly rinse with water.

Wet hands, rub palms together, interlink your fingers, rub palms with your fingers, rub the back of hands, then thoroughly rinse with water.

I don't know

23. Best method after sneezing and coughing to reduce transmission of COVID-19

Cover mouth and nose with arm

Cover mouth and nose with tissue

Cover mouth and nose with tissue and then washing hands

I don't know

24. If COVID-19 common symptoms appear, patient most do the following:

Wear face mask, wear gloves, wear face shield

wear face shield, Wear face mask and stay at home

Wear face mask, wear gloves and contact the emergency 937

Wear face mask, wear gloves and stay at home

25. what you will do in the following situations:

In case of you visit fever clinic and your result was negative, what you will do?

Commitment to preventive precautions that applied by $\mathrm{MOH}$

Home isolation for 10 days

Home quarantine for 14 days

call 937

In case of you visit fever clinic and your result was negative, and you are in previous contact with COVID-19 confirmed case. What you will do?

Commitment to preventive precautions that applied by $\mathrm{MOH}$

Home isolation for 10 days

Home quarantine for 14 days

call 937

In case of you visit fever clinic and your result was positive without symptoms, and you aren't in previous contact with COVID-19 confirmed case. What you will do?

Commitment to preventive precautions that applied by $\mathrm{MOH}$

Home isolation for 10 days

Home quarantine for 14 days

call 937

In case of you visit fever clinic and your result was positive with severe symptoms. What you will do?

Commitment to preventive precautions that applied by $\mathrm{MOH}$

Home quarantine for 10 days

Home quarantine for 14 days

call 937

26. The condition that is required for patients who need home isolation:

Separate bathroom, staying in private room, Surface disinfection, especially door handles, open window frequently, use disposable materials that is for one use only.

- Private room, surface disinfect.

(a) Private room, open window frequency.

I don't know

27. Do you think if there was vaccination to COVID-19:

Yes

No

I don't know 
28. Do you think one of this condition can decrease the possibility of getting infected with COVID-19:

Using of antibiotics.

Using herbal medication and products

Using face mask

Smoking cessation

29. From where you got your information about COVID-19 prevention method:

Internet website

Social media

Ministry of Health

From family and friends

30. In the case of positive COVID-19 Patient and there is no place for isolation in his house, what he most does:

- Go to hotels

- Contact the emergency

$\bigcirc \quad$ Take precautions at home

I I do not know

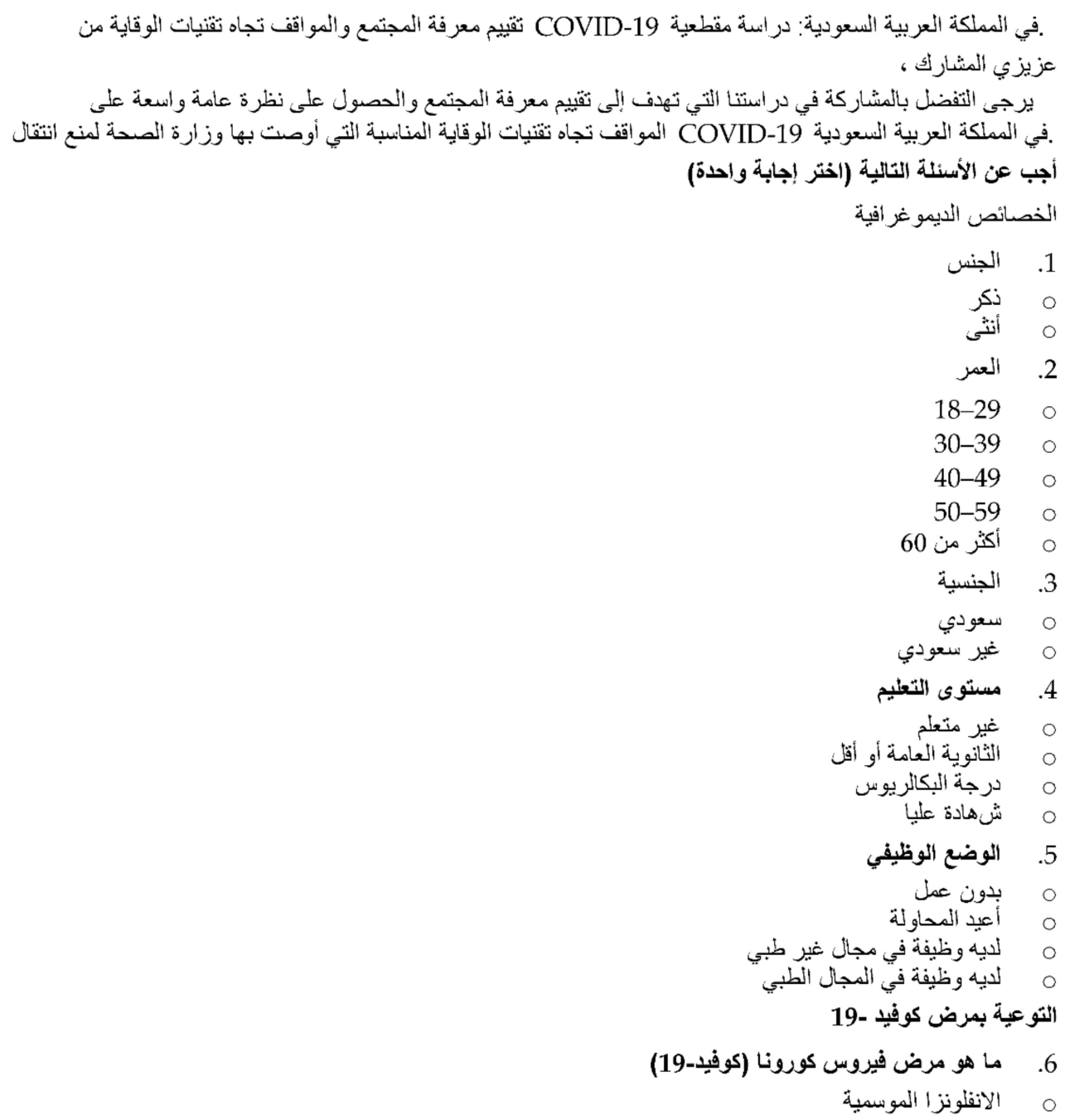




$$
\begin{aligned}
& \text { م مرض نزلات البرد } \\
& \text { 0 }
\end{aligned}
$$

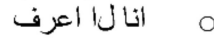

$$
\begin{aligned}
& \text { 7. } \\
& \text { O } \\
& \text { 0 في المملكه العربيه السعوديه }
\end{aligned}
$$

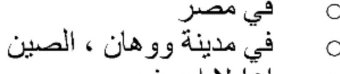

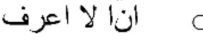

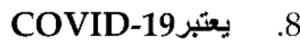

$$
\begin{aligned}
& \text { م عدوى فيروسية } \\
& \text { م مدوى بكتيرية } \\
& \text { م }
\end{aligned}
$$

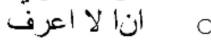

9. بمكن أن ينتقل COVID-19 عن طريق (يمكنك اختيار أكثر من إجابة واحدة)

$$
\text { 0 } 0
$$

10. أعراض COVID-19 هي (يمكنث اختيار أكثر من إجابة واحدة)

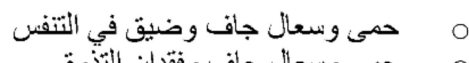

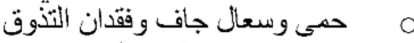
O ممى ، قيء ، طفح جلدي

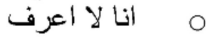

11. من المرجح أن بكون Covid-19 شديدًا في

م الأطفال من المرجن

0 كبار السن ولديهم أمر اض مزمنة

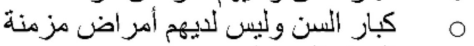

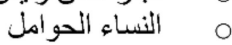

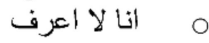

الموقف من مرض كوفيد -19 أن

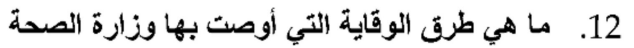

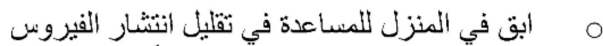

O المسافة بينك وبين شريكلك في 2 إلمى 3 أمتار

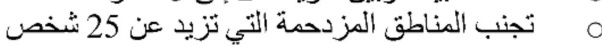

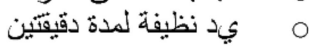

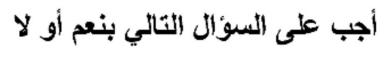

13. هل مكثت في المنزل للعد من انتثار الفيروس معظم أيام الأسبوع 5) أيام أو أكثر)

م أخرج في حالة الطوارئ

14. هل حضرت أي موقع احتفال يضم أكثر من 50 شخصنا؟

15. هل حافظت على مسافة (1 إلى 2 متر) بينك وبين الآخرين لتجنب انتشارCOVID-19

16. هل تجنبت مؤخرًا سنوكيات ثقافية مثل المصافحة؟

17. هل تطم إذا كان لدينا أي علاج قابل للشفاء 


$$
\begin{array}{rr}
ل & 0 \\
\hline & 0
\end{array}
$$

18. هل غنلت بدك بالماء و الصابون بعد الحالة التالية

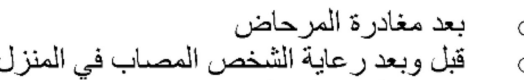

$$
\begin{aligned}
& \text { م بعد العطس و السعال } \\
& \text { م بعد لمس الحيو انات (الحيو انات الالليفة) } \\
& \text { O بعد لمس القمامة } \\
& \text { مبل الوجبة }
\end{aligned}
$$

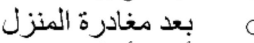

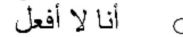

19. كم ثانية يجب أن نأخذها في غسل أيدينا؟ م

م

O

م

20. هل استخدمت النظافة الكحولية إذا كاتت الإجابة بنعم إلى متى

م

O

م

م 10

21. ل هل تعتقد أن أي من الإجراءات التالية قد يقلل من خطر الإصابة بـ COVID-19

$$
\text { م }
$$

22. في خطوات غسل اليدين يجب مراعاتها.

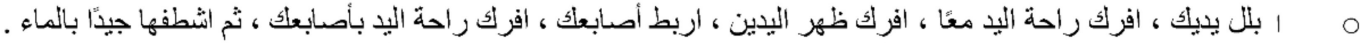

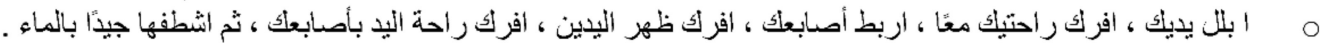

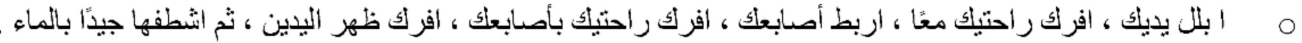

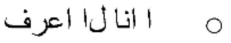

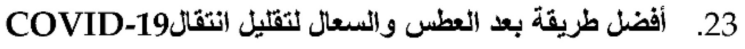

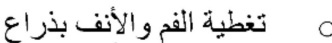
م تغطية الفم والأنف بالمنديل

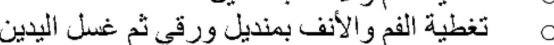

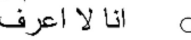

24. في حالة ظهور الأعز اض الشائعة لــCOVID-19 ، يقوم المريض في الغالب بما يلي:

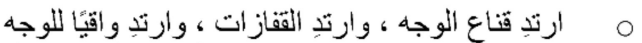

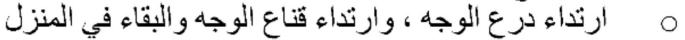

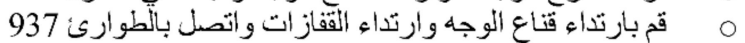

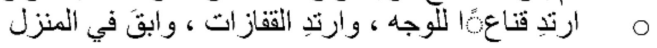

25. ما سنفعله في المواقف التالبة:

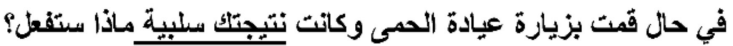

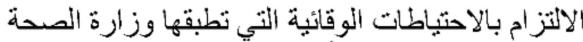

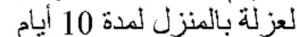
الحجر المنزلي لمدة لمدة 14 يومًا م التصل بالرقم 937

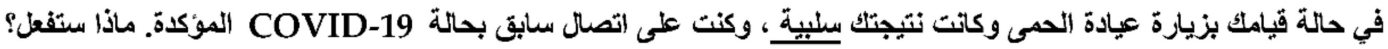

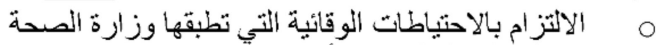

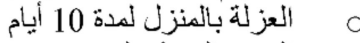

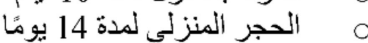
م

في حالة زيارتك لعيادة الحمى وكانت نتيجتك إيجابية بدون أعراض ، ولم تكن على اتصال سابث بحالة COVID-19 المؤكدة. ماذا ستفعل؟ 


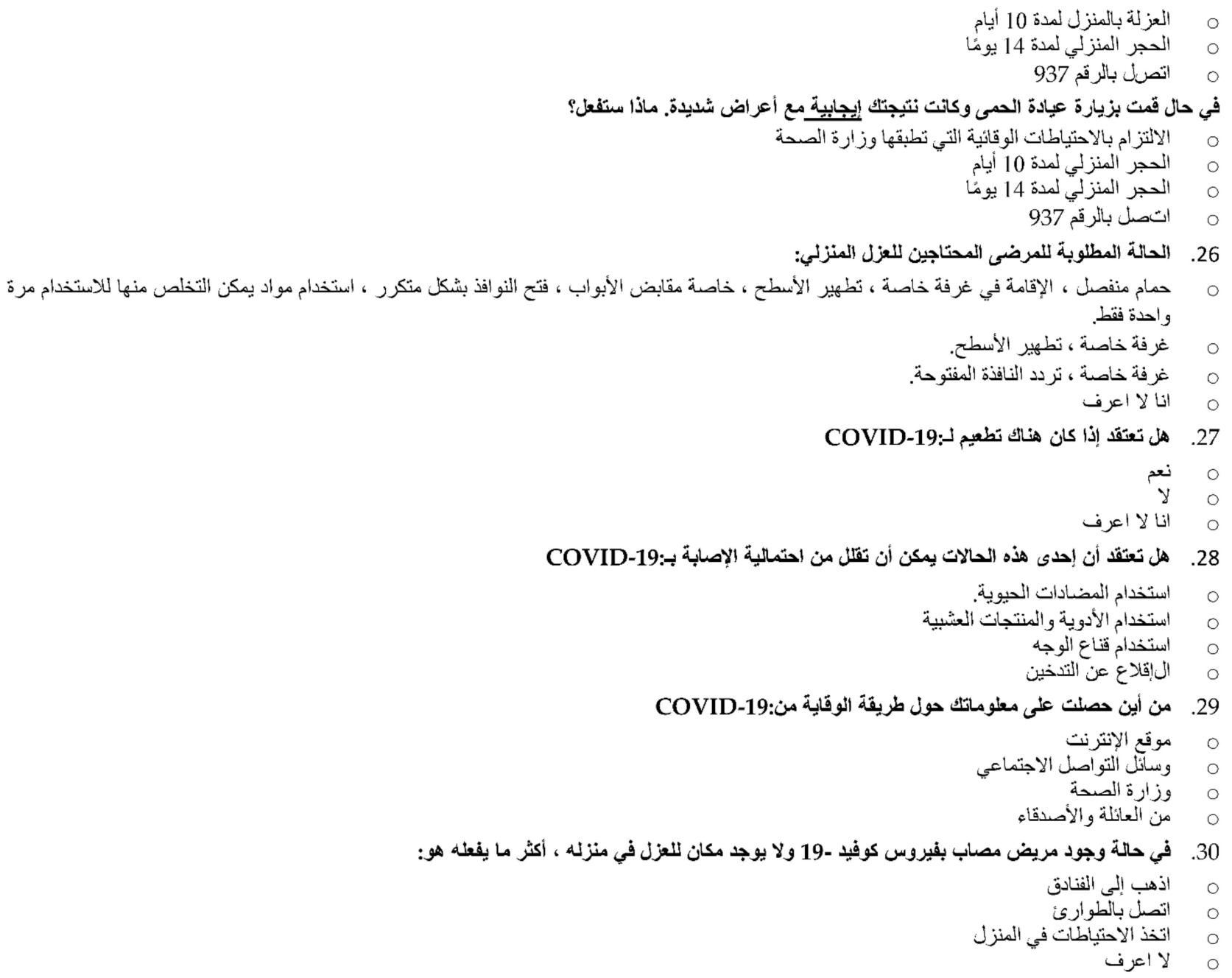

\section{References}

1. McIntosh, K. COVID-19: Epidemiology, Virology, and Prevention. 9 September 2021. Available online: https://www.uptodate. $\mathrm{com} /$ contents / coronavirus-disease-2019-covid-19-epidemiology-virology-and-prevention?search=coronavirus\&source= search_result\&selectedTitle=1 \{1\}150\&usage_type=default\&display_rank=1 (accessed on 30 October 2021).

2. MAYO Clinic. Coronavirus Disease 2019 (COVID-19). 9 September 2021. Available online: https://www.mayoclinic.org/ diseases-conditions / coronavirus/symptoms-causes/syc-20479963 (accessed on 30 October 2021).

3. Siddell, S.; Anderson, R.; Cavanagh, D.; Fujiwara, K.; Klenk, H.; Macnaughton, M.; Pensaert, M.; Stohlman, S.; Sturman, L.; Van der Zeijst, B. Coronaviridae. Intervirology 1983, 20, 181-189. [CrossRef] [PubMed]

4. Helmy, Y.A.; Fawzy, M.; Elaswad, A.; Sobieh, A.; Kenney, S.P.; Shehata, A.A. The COVID-19 Pandemic: A Comprehensive Review of Taxonomy, Genetics, Epidemiology, Diagnosis, Treatment, and Control. J. Clin. Med. 2020, 9, 1225. [CrossRef] [PubMed]

5. Rotondo, J.C.; Martini, F.; Maritati, M.; Mazziotta, C.; Di Mauro, G.; Lanzillotti, C.; Barp, N.; Gallerani, A.; Tognon, M.; Contini, C. SARS-CoV-2 Infection: New Molecular, Phylogenetic, and Pathogenetic Insights. Efficacy of Current Vaccines and the Potential Risk of Variants. Viruses 2021, 13, 1687. [CrossRef]

6. Zhou, Z.; Qiu, Y.; Ge, X. The taxonomy, host range and pathogenicity of coronaviruses and other viruses in the Nidovirales order. Anim. Dis. 2021, 1, 1-28. [CrossRef] [PubMed]

7. Ehsanifar, M. Airborne aerosols particles and COVID-19 transition. Environ. Res. 2021, 200, 111752. [CrossRef] [PubMed]

8. Cascella, M.; Rajnik, M.; Aleem, A.; Dulebohn, S.; Di Napoli, R. Features, Evaluation, and Treatment of Coronavirus (COVID-19). StatPearls. 2021. Available online: https:/ / pubmed.ncbi.nlm.nih.gov/32150360/ (accessed on 30 October 2021).

9. Hodcroft, E.B. CoVariants: SARS-CoV-2 Mutations and Variants of Interest. 16 October 2021. Available online: https://covariants. org / (accessed on 30 October 2021).

10. Hodcroft, E.; Lauring, A. Genetic variants of SARS-CoV-2-What do they mean? JAMA 2021, 325, 529-531.

11. Vasireddy, D.; Vanaparthy, R.; Mohan, G.; Malayala, S.V.; Atluri, P. Review of COVID-19 Variants and COVID-19 Vaccine Efficacy: What the Clinician Should Know? J. Clin. Med. Res. 2021, 13, 317-325. [CrossRef] 
12. Wolf, M.S.; Serper, M.; Opsasnick, L.; O'Conor, R.M.; Curtis, L.M.; Benavente, J.Y.; Wismer, G.; Batio, S.; Eifler, M.; Zheng, P.; et al. Awareness, Attitudes, and Actions Related to COVID-19 Among Adults With Chronic Conditions at the Onset of the U.S. Outbreak: A Cross-sectional Survey. Ann. Intern. Med. 2020, 173, 100-109. [CrossRef] [PubMed]

13. Alwafi, H.; Naser, A.Y.; Qanash, S.; Brinji, A.S.; Ghazawi, M.; Alotaibi, B.; Alghamdi, A.; Alrhmani, A.; Fatehaldin, R.; Alelyani, A.; et al. Predictors of Length of Hospital Stay, Mortality, and Outcomes Among Hospitalised COVID-19 Patients in Saudi Arabia: A Cross-Sectional Study. J. Multidiscip. Health 2021, 14, 839-852. [CrossRef]

14. Alyami, H.S.; Naser, A.Y.; Dahmash, E.Z.; Alyami, M.H.; Alyami, M.S. Depression and anxiety during the COVID-19 pandemic in Saudi Arabia: A cross-sectional study. Int. J. Clin. Pract. 2021, 75, e14244. [CrossRef] [PubMed]

15. Badr, O.; Alwafi, H.; Elrefaey, W.; Naser, A.; Shabrawishi, M.; Alsairafi, Z.; Alsaleh, F. Incidence and Outcomes of Pulmonary Embolism among Hospitalized COVID-19 Patients. Int. J. Environ. Res. Public Health 2021, 18, 7645. [CrossRef]

16. Zawawi, A.; Naser, A.Y.; Alwafi, H.; Minshawi, F. Profile of Circulatory Cytokines and Chemokines in Human Coronaviruses: A Systematic Review and Meta-Analysis. Front. Immunol. 2021, 12, 666223. [CrossRef] [PubMed]

17. Shabrawishi, M.; Al-Gethamy, M.M.; Naser, A.Y.; Ghazawi, M.A.; Alsharif, G.F.; Obaid, E.F.; Melebari, H.A.; Alamri, D.M.; Brinji, A.S.; Al Jehani, F.H.; et al. Clinical, radiological and therapeutic characteristics of patients with COVID-19 in Saudi Arabia. PLoS ONE 2020, 15, e0237130. [CrossRef] [PubMed]

18. Al-Mohrej, O.A.; Al-Shirian, S.D.; Al-Otaibi, S.K.; Tamim, H.M.; Masuadi, E.M.; Fakhoury, H.M. Is the Saudi public aware ofMiddle East respiratory syndrome? J. Infect. Public Health 2016, 9, 259-266. [CrossRef]

19. El-Gharabawy, R.; Abdallah, A.S.; Aldowyan, N. Knowledge, Attitude and Practice (KAP) Study about Middle East Respiratory Syndrome Coronavirus (MERS-CoV) among Population in Saudi Arabia. Int. Arch. Med. 2017, 10. [CrossRef]

20. Worldometer. Saudi Arabia, 26 November 2021. Available online: https:/ /www.worldometers.info/coronavirus/country/saudiarabia/(accessed on 30 October 2021).

21. Al-Hanawi, M.; Angawi, K.; Alshareef, N.; Qattan, A.M.N.; Helmy, H.Z.; Abudawood, Y.; AlQurashi, M.; Kattan, W.; Kadasah, N.A.; Chirwa, G.C.; et al. Knowledge, Attitude and Practice Toward COVID-19 Among the Public in the Kingdom of Saudi Arabia: A Cross-Sectional Study. Front. Public Health 2020, 8, 217. [CrossRef] [PubMed]

22. Naser, A.; Dahmash, E.; Alsairafi, Z.; Alwafi, H.; Alyami, H.; Jalal, Z.; Al Rajeh, A.; Paudyal, V.; Alhartani, Y.; Turkistani, F.; et al. Knowledge and Practices during the COVID-19 Outbreak in the Middle East: A Cross-Sectional Study. Int. J. Environ. Res. Public Health 2021, 18, 4699. [CrossRef] [PubMed]

23. Alqahtani, A.S.; Wiley, K.; Willaby, H.; BinDhim, N.F.; Tashani, M.; Heywood, A.; Booy, R.; Rashid, H. Australian Hajj pilgrims' knowledge, attitude and perception about Ebola, November 2014 to February 2015. Eurosurveillance 2015, 20, 21072. [CrossRef] [PubMed]

24. Leung, G.; Quah, S.R.; Ho, L.-M.; Ho, S.-Y.; Hedley, A.J.; Lee, H.-P.; Lam, T.-H. A tale of two cities: Community psychobehavioral surveillance and related impact on outbreak control in Hong Kong and Singapore during the severe acute respiratory syndrome epidemic. Infect. Control. Hosp. Epidemiol. 2004, 25, 1033-1041. [CrossRef]

25. Yap, J.; Lee, V.J.; Yau, T.Y.; Ng, T.P.; Tor, P.-C. Knowledge, attitudes and practices towards pandemic influenza among cases, close contacts, and healthcare workers in tropical Singapore: A cross-sectional survey. BMC Public Health 2010, 10, 442. [CrossRef]

26. Desai, A.N.; Patel, P. Stopping the Spread of COVID-19. JAMA 2020, 323, 1516. [CrossRef] [PubMed]

27. World Health Organization. Coronaviruses (COVID-19). 2020. Available online: https://www.who.int/news-room/q-a-detail/ q-a-coronaviruses (accessed on 30 October 2021).

28. Centre for Disease Control and Prevention. Coronavirus (COVID-19). 2020. Available online: https:/ /www.cdc.gov/coronavirus / 2019-nCoV/index.html (accessed on 30 October 2021).

29. Abdelhafiz, A.S.; Mohammed, Z.; Ibrahim, M.E.; Ziady, H.H.; Alorabi, M.; Ayyad, M.; Sultan, E. Knowledge, Perceptions, and Attitude of Egyptians Towards the Novel Coronavirus Disease (COVID-19). J. Community Health 2020, 45, 881-890. [CrossRef]

30. Abukhalaf, A.H.I.; von Meding, J. Psycholinguistics and emergency communication: A qualitative descriptive study. Int. J. Disaster Risk Reduct. 2021, 55, 102061. [CrossRef]

31. Abukhalaf, A.H.I.; von Meding, J. Integrating international linguistic minorities in emergency planning at institutions of higher education. Nat. Hazards 2021, 109, 845-869. [CrossRef]

32. Al Shehri, A.M. A lesson learned from Middle East respiratory syndrome (MERS) in Saudi Arabia. Med. Teach. 2015, 37 (Suppl. 1), S88-S93. [CrossRef] [PubMed]

33. Almutairi, K.M.; Al Helih, E.M.; Moussa, M.; Boshaiqah, A.E.; Alajilan, A.S.; Vinluan, J.M.; Almutairi, A. Awareness, Attitudes, and Practices Related to Coronavirus Pandemic Among Public in Saudi Arabia. Fam. Community Health 2015, 38, 332-340. [CrossRef] [PubMed]

34. Madani, T. Preventive strategies to keep Saudi Arabia SARS-free. Am. J. Infect. Control 2004, 32, 120-121. [CrossRef] [PubMed]

35. Nooh, H.Z.; Alshammary, R.H.; Alenezy, J.M.; Alrowaili, N.H.; Alsharari, A.J.; Alenzi, N.M.; Sabaa, H.E. Public awareness of coronavirus in Al-Jouf region, Saudi Arabia. J. Public Health 2020, 13, 1-8. [CrossRef] [PubMed]

36. Elbur, A.; Alharthi, A.; Aljuaid, A.; Hasan, N. Knowledge of Middle East Respiratory Syndrome Coronavirus (MERS-CoV) and its Management: A Survey among Saudi People in Taif; Kingdom of Saudi Arabia. IOSR J. Pharm. 2016, 6, 33-39. [CrossRef]

37. Zhong, B.-L.; Luo, W.; Li, H.-M.; Zhang, Q.-Q.; Liu, X.-G.; Li, W.-T.; Li, Y. Knowledge, attitudes, and practices towards COVID-19 among Chinese residents during the rapid rise period of the COVID-19 outbreak: A quick online cross-sectional survey. Int. J. Biol. Sci. 2020, 16, 1745-1752. [CrossRef] 
38. Alyami, M.H.; Naser, A.Y.; Orabi, M.A.A.; Alwafi, H.; Alyami, H.S. Epidemiology of COVID-19 in the Kingdom of Saudi Arabia: An Ecological Study. Front. Public Health 2020, 8, 506. [CrossRef] [PubMed]

39. Azlan, A.A.; Hamzah, M.R.; Sern, T.J.; Ayub, S.H.; Mohamad, E. Public knowledge, attitudes and practices towards COVID-19: A cross-sectional study in Malaysia. PLoS ONE 2020, 15, e0233668. [CrossRef] [PubMed]

40. Hoda, J. Identification of information types and sources by the public for promoting awareness of Middle East respiratory syndrome coronavirus in Saudi Arabia. Health Educ. Res. 2016, 21, 12-23. [CrossRef]

41. Reigal, R.E.; Pastrana, J.L.; González-Ruiz, S.L.; Hernández-Mendo, A.; Morillo-Baro, J.P.; Morales-Sánchez, V. Use of Data Mining to Determine Usage Patterns of an Online Evaluation Platform During the COVID-19 Pandemic. Front. Psychol. 2020, 11, 588843. [CrossRef] [PubMed] 